\title{
English for Islamic Studies Teaching Model : It's Effect on Students English Achievement
}

\author{
Melyann Melani ${ }^{1}$ \\ ${ }^{1}$ Faculty of Teachers Training, State Islamic Institute of Bukittinggi, Bukittinggi, Indonesia \\ "melyannmelani@gmail.com\}
}

\begin{abstract}
Identifying the effectiveness of English for Islamic Studies Teaching Model (referred to as EISTIM) is part of a series of research and development that was aimed at creating a teaching model used in English for Islamic Studies subject at Islamic Studies Study Program, Faculty of Teachers Training, IAIN Bukittinggi. EISTIM was designed based on a thorough need analysis and had been proven valid and practical to some extent. This study was aimed at identifying whether or not this model is effective in improving students' English achievement. It involved 71 students' which were divided into experiment and control groups. Both groups were given a pre-test and followed with a post-test to measure their English achievement before and after the treatment. The result of the study indicated the students from the experimental group have a significantly higher mean score as compared to the students from the control group.
\end{abstract}

Keywords: EISTIM; English Achievement

\section{Introduction}

English for Specific Purpose is explained as an approach to the teaching of language where all decision regarding the content and method are made on the basis of students' reason for learning, (Hutchinson and Waters, 1987). Developing an effective ESP program is not without challenges. There are numbers of methodological issues speculating around ESP. These issues includes .difficulties associated with aspects of ESP pedagogy ( $\mathrm{Yu}$ and Xiao, 2013; Gao, 2007; Rasekh and Valizadeh, 2004). Several issues related to lecturers' lack of knowledge and skills also emerged, (Gafournia and Sabet, 2014; Northcott and Brown, 2006). Finally, contextual constrains related to the location where ESP is taught is also regarded as a challenge of practicing ESP.

Based on preliminary research, ESP practiced at English for Islamic Studies Study Program also faced some problems. Several books on English for Islamic Studies are available. Unfortunately, the books only contain some reading passages followed by exercises. There is no practical guidance on how to teach the material in a communicative way and on how to teach the reading materials integrated with other language skill (listening, speaking and writing). Lecturers complained that they didn't have enough resources and support to develop their own ESP lesson. Students had difficulties in understanding the text in ESP books which are caused by the text difficulty level as well as poor English proficiency. EITISM is expected to be able to help both lecturer and students to practice ESP in a more effective way. The 
teaching model is designed based on the result of need analysis and it is accompanied with lecturers and students book as well as the teaching model book.

\section{Literature Review}

\section{A. English for Islamic Studies Teaching Model (EISTIM)}

EISTISM falls into the category of Information Processing Model, which basically rooted in the constructivism as its philosophical base. This model represents what happens when information flows through various internal structures which exist inside the students. By having a good understanding of how the information is processed, stored and retrieved through the Information Processing Model, students would be able to learn much more efficiently and systematically. In teaching receptive skills (Reading and Listening), information processing model resembles the schema theory. Schema theory believes that active involvement in reading happens if the reader or listener actively relate new information with already excited information.

The element of Flipped Classroom Teaching Model is also incorporated into EISTIM as it reverse the situation of traditional teaching and integrate technological tool as teachers are dealing with technology literate students, (Afrilyasanti, Cahyono \& Astuti, 2017). New Learning materials are introduced prior to classroom sessions as homework (Clark, 2014) as it allows teacher to save time teaching the whole things and help the students construct their own knowledge (Sohrabi \& Iraj, 2016). Flipped Classroom also inverted students' cognitive level. It enables teacher to allocate a more active learning activities to take place in classroom session. Classroom session is mainly use to develop High Order Thinking Skill (HOTS) on the other hand, Low Order Thinking Skill (LOTS) are polished at home as homework (Williams, 2013).

EISTIM has five important components; (1) Syntax; (2) Social Systems; (3) Principles of Reaction; (4) Support Systems; and (5) Instructional and Nurturant effect. Syntax, the first component of the model, consists of five simple steps. They are:

- Introducing new materials. Prior to classroom sessions, the students are given homework related to new material. The students are expected to read passages, watch videos, listen to news, doing online quizzes through the use of mobile devices and computers. Homework is done in a paperless way. Homework is announced and collected by using Google Classroom as the learning platform. The activities in this stage employ LOTS, C1 and C2.

- Presenting homework. Before the class starts, the students are randomly selected to present their homework to the whole class in the form of summary or conclusion of passages, report of listening task and results of online quizzes.

- $\quad$ Pre-reading/listening. It is the stage where student's schemata is activated and developed. In activating schemata, the lecturers need to find out information on what the students already know as well as the structure (language) of the reading or listening passage. Exercises for schema activation comprise of showing a picture or asking some questions. Schema developing activities deals with activities that help students develop schemata which are not available in their background knowledge. Schema development activities may include background information related the author or speakers; when and where the passage was written or the conversation takes place; cultural and historical information in the passages or listening materials; technical or specialized information on the passages or listening materials 
- While-reading/listening. In this stage, the lecturer is responsible to monitor and ensure students comprehension and to teach language component (vocabulary or grammar). Whilereading/listening stage is where the students' comprehension is most likely fall apart, and often leads to frustration and confusion. During reading/listening activities are important when the passages or listening materials is long, the content and language are not familiar to the students or when the genre is challenging. Dividing the passages or listening materials into several sections, providing a set of guiding questions to respond to as the students are reading or listening and a graphic format are some activities that can be done to facilitate comprehension. Activities in this stage belong to HOTS category, $\mathrm{C} 3$ and $\mathrm{C} 4$

- After-reading/listening. After Reading stage is the stage where the students have $\mathrm{read} /$ listened to the passages for several times, have comprehended important parts and have spent time analysing the text's language and structure. This stage help students evaluate and extend what they have learned by doing speaking or writing activities like making summary or reflecting to what the students read/listen to. The lecturers should also encourage the students to create class project related to materials that they have learned. This stage uses HOTS (C5 and C6)

The second component of the model is social system which describes the relationship between learner and lecturer. The emphasis on learner active participation and role of the learner make this model is students' centered teaching model since it promotes learner autonomy. The third component of EISTIM is the principle of reaction which points out that the lecturer functions as the facilitator, the person who monitors and evaluates the learning process. Principle of reaction tells the teacher how to regard the students and how to responds to what the students do.

The next component of the teaching model is support system that provides support for the model to work effectively. Support system describes the supporting conditions required to implement the model. Support refers to additional requirements beyond the usual human skill, capacities and technical facilities. This includes books, films, online reading/listening materials, reference materials, etc. The last component is the instructional and nurturant effect which brings the students to become autonomous learner. 


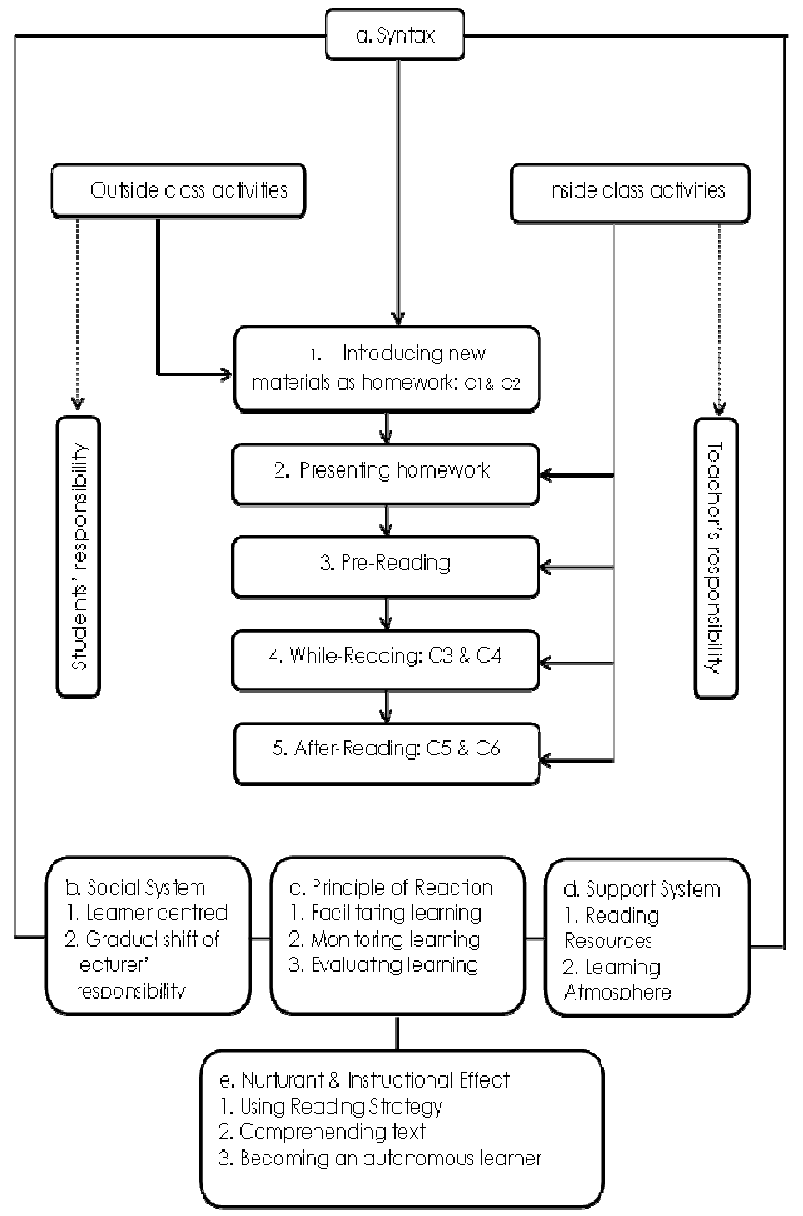

Figure 1. English for Islamic Studies Teaching Model (EISTM)

\section{B. English Achievement}

Achievement is described as how well students have learned or what they are expected to know. As for this research it is important to collect information on what aspect of the lesson that the students already understand or acquire. In order to measure students' achievement on the lesson, an achievement test is used. An achievement test measures knowledge of specific information or what students already know. Achievement test evaluates learners' understanding of a specific course or study program and measures how much the students have learned in a specific time. Achievement tests have educational and diagnostic purposes that they can help the lecturer and the students to investigate which area needs to improve. 


\section{Research Methodology}

This study employs pre-experimental research, with pre-test-post-test control group design (Gay, 2009). This design involves two groups, experiment and control which involved 71 students taking English for Islamic Studies Subject. Both groups are administered a pre-test prior to the experiment and followed with the post-test. The experiment group was given treatment by using EISTIM meanwhile control group was given treatment of the traditional teaching method. An achievement test was used as the instrument for the pre-and post-test. Below is the description of instructional activities of the two groups.

Table 2. Instructional Activities

\begin{tabular}{lll}
\hline No & $\begin{array}{l}\text { Instructional Activities } \\
\text { Experiment Class }\end{array}$ & Control Class \\
\hline 1 & Introducing new materials as homework & Pre-reading \\
2 & Presenting homework & While-reading \\
3 & Pre-reading/listening & After-reading \\
4 & While-reading/listening & Homework \\
5 & After-reading/listening & - \\
\hline
\end{tabular}

\section{Result and Discussion}

Before the result of the study is revealed, it is better to describe the result of the homogeneity test and normality test as requirements that should be fulfilled prior to conducting t-test.

Table 3. Normality Test

\begin{tabular}{|c|c|c|c|c|}
\hline & \multirow[t]{2}{*}{ Class } & \multicolumn{3}{|c|}{$\begin{array}{c}\text { Kolmogorov- } \\
\text { Smirnov }^{\mathrm{a}}\end{array}$} \\
\hline & & $\begin{array}{l}\text { Stat } \\
\text { istic }\end{array}$ & df & Sig. \\
\hline \multirow{5}{*}{$\begin{array}{l}\text { Students } \\
\text { Score }\end{array}$} & Pre-Test & .119 & 36 & .200 \\
\hline & Experiment & & & \\
\hline & Post-Test & .157 & 36 & .024 \\
\hline & Pre-Test & .164 & 35 & .018 \\
\hline & $\begin{array}{c}\text { Control } \\
\text { Post-Test } \\
\text { Control }\end{array}$ & .148 & 35 & .049 \\
\hline
\end{tabular}

The result of the normality test indicated that the significance level is higher than 0,05 . It means that the data is normally distributed.

Table 4. Homogeneity Test

Test of Homogeneity of Variance

\begin{tabular}{rrrrr}
\hline Test of Homogeneity of Variance & \\
\hline Levene & df & df2 & Sig. \\
Statistic & 1 & & \\
\hline
\end{tabular}




\begin{tabular}{llllll}
\hline Score & Mean & 1.201 & 3 & 138 & .312 \\
& & & & & \\
\hline
\end{tabular}

The result of the homogeneity test indicated that the significance level is 0,312 which is higher than 0,05 . It means that the data is homogenous.

Hypothesis testing is intended to prove that EISTIM help students to have better English achievement. Thus the hypotheses for this research are; (Ho): Students English achievement by using EISTIM is the same with students' English achievement by using traditional teaching model and (Ha): Students' Students English achievement by using EISTIM is better than students' English achievement by traditional teaching model. The consideration to decide whether the hypotheses are accepted or not is when the score for (2-tailed) $i s>0,005$ then (Ho) is accepted and (Ha) is rejected. The result of the computation is shown in the following chart:

Table 5. Independent Sample Test

\begin{tabular}{cccccc}
\hline \multicolumn{5}{c}{ Group Statistics } & \\
& Class & $\mathrm{N}$ & Mean & $\begin{array}{c}\text { Std. } \\
\text { Deviati } \\
\text { on }\end{array}$ & $\begin{array}{c}\text { Std. } \\
\text { Error } \\
\text { Mean }\end{array}$ \\
\hline $\begin{array}{c}\text { Gain } \\
\text { sco } \\
\text { re }\end{array}$ & $\begin{array}{c}\text { Experime } \\
\text { nt } \\
\text { Control }\end{array}$ & 36 & .3838 & .15061 & .02510 \\
\hline
\end{tabular}

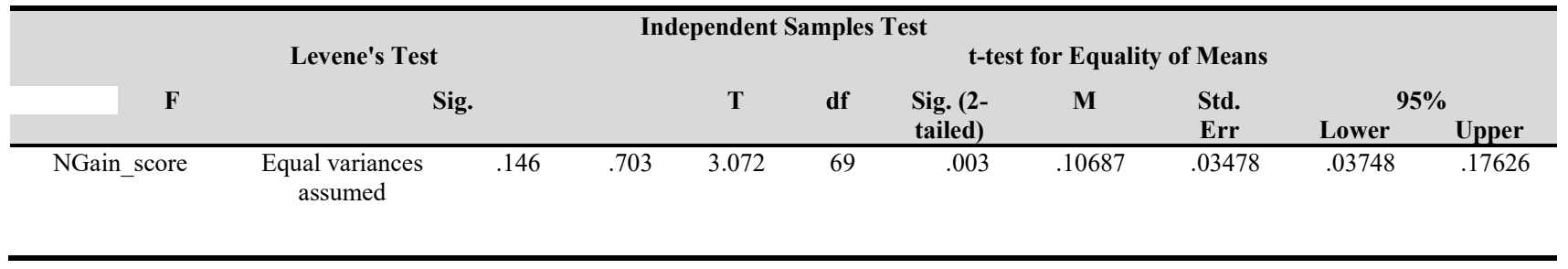

Table 5 above indicated that the score for $1 / 2$ Sig for two-tailed test for homogeneous variances is 0,03 which is smaller than alpha $(0,05)$. Because the score of $1 / 2 \mathrm{Sig}$. of independent sample test does not exceed alpha $(0,05)$, it indicates that null hypotheses (Ho) is rejected and alternative hypotheses $(\mathrm{Ha})$ is accepted. It can be concluded form the hypotheses testing that there is a significant effect of using EISTIM toward the students' English achievement.

Thus, the result of the study indicated that EISTIM was proven effective in improving students' English achievement. There are several factors that can be related to the element of the teaching model that contribute to the result of the study. First, the active engagement of the students in constructing knowledge helps them understand, process and stored new knowledge. It resembles the constructivism approach to teaching English (Aljohani, 2017; Mvududu \& Thiel-Burgess, 2012; Dev, 2016). The first stage of the teaching model where new materials are introduced by giving homework in the form of reading passages, watching videos, listening to news and doing online quizzes through the use of mobile devices and computers put learner as an active participant in the teaching process. It enables students to activate and develop their background knowledge before the class session starts. Therefore, it 
is easier for the students to relate with the new information as well as to store the new information in their long term memory.

The second factor related to the teaching model that contributes to the result of the study is skill integrated element in the lesson. Integrated skill approach that put together reading, listening, speaking and writing has become more popular because it is believed to be able to teach English more effectively and help improve English proficiency (Pardede, 2019; Gautam, 2019; Rahman \& Akhter, 2019). Skill segregation that seemed to be the case in most ESP books is considered outdated and has become less popular.

Finally, the use of technology based learning platform has helped improve students' engagement as well as motivation in learning. Using Google Classroom for organizing students' homework is suitable with the merits of the 21 st-century education where the concept of learning shifts from listening to teachers passively to actively applying and pursuing knowledge. Using technology in the classroom has been proven to be more effective as compared to traditional classroom teaching (Aziz, 2018; Smadi et al., 2020; Chun et al., 2016)

\section{References}

[1] Afrilyasanti, R, Cahyono, B. Y., \& Astuti, U. P. (2017). Indonesian EFL Students' Perceptions on the Implementation of Flipped Classroom Model. Journal of Language Teaching and Research.

[2] Aljohani, M. (2017). Principles of Constructivism in Foreign Language Teaching. Journal of Literature and Art Studies. 7. pp.97-107

[3] Aziz, A. (2018). Education 4.0 Made Simple: Ideas For Teaching. International $\begin{array}{lllll}\text { Journal of Education and Literacy Studies, } & 6(3), & 92 .\end{array}$ https://journals.aiac.org.au/index.php/IJELS/article/view/4616

[4] Chun, D., Smith, B., \& Kern, R. (2016). Technology in Language Use, Language Teaching, and Language Learning. Modern Language Journal, 100, 64-80. https://doi.org/10.1111/modl.12302

[5] Clark, K. R. (2014). Examining the effects of the flipped model of instruction on student engagement and performance in the secondary mathematics classroom: An action research study. Dissertation Abstracts International Section A: Humanities and Social Sciences. https://doi.org/3592584

[6] Dev, M. (2016). Constructivist Approach Enhances the Learning: A Search of Reality. Journal of Education and Practice. 7(25).pp. 59-62

[7] Gautam. (2019). Integrated and Segregated Teaching of Language Skills: An Exploration. Journal of NELTA Gandaki. Vol.1 pp. 100-107

[8] Gao, J. (2007). Designing an ESP course for Chinese university students of business. The Asian ESP Journal, 3(1), 97-106

[9] Gay. (2009). Educational research. New Jersey: Prentice Hall.

[10] Ghafournia, N., \& Sabet, S. A. (2014). The most prominent roles of an ESP teacher. International Education Studies, 7(11), 1-9.

[11] Hutchinson, T., \& Waters, A. (1987). English for Specific Purposes: A LearnerCentered Approach. Cambridge: Cambridge University Press 
[12] Mvududu, N \& Thiel-Burgess, J. (2012). Constructivism in Practice: The Case for Language Learner. International Journal of Education. Vol.4 No.3. pp. 108-118

[13] Northcott, J., \& Brown, G. (2006). Legal translator training: Partnership between teachers of English for legal purposes and legal specialists. English for Specific Purposes, 25(3), 358-375.

[14] Pardede, P. 2019. Integrated Skills Approach in EFL Classroom: A literature Review. EED Collegiate Forum. pp.147-159

[15] Rahman, S \& Akhter,A 2019. Skills Teaching in ESL Classroom: Discrete and Integrated. International Journal of English Language Teaching. 5(4). pp. 32-39

[16] Rasekh, Z., \& Valizadeh K. (2004). Classroom activities viewed from different perspectives: Learners' voice vs. teachers' voice. TESL-EJ, 8(3), 1-13.

[17] Smadi, M. A.-L. M., Mohammad, A. H., \& Rahman, F. A. (2020). Barriers in Instructional Technology Integration in Teachers in Social Studies at Jordan Elementary School. Pedagogia: Jurnal Pendidikan, 9(1), 35-44. https://doi.org/10.21070/pedagogia.v9i1.124

[18] Sohrabi, B., \& Iraj, H. (2016). Implementing flipped classroom using digital media: A comparison of two demographically different groups perceptions. Computers in Human Behavior. https://doi.org/10.1016/j.chb.2016.02.056

[19] Williams, B. (2013). How I flipped my classroom. NNNC Conference.

[20] Yu, X., \& Xiao, Y. (2013). A course design guideline for legal English teaching in Chinese tertiary education: From the perspective of content-based instruction. Theory and Practice in Language Studies, 3(7), 1123-1128. 